\title{
Bioactives properties of extracts from moroccan oil shale
}

\author{
Mina OUMAM, Abdelkrim ABOURRICHE and Hassan HANNACHE \\ Laboratoire des Matériaux Thermostructuraux, Faculté des Sciences Ben M'Sik, BP 7955, Casablanca, \\ Maroc \\ Abdelmjid ABOURRICHE, Ahmed BENNAMARA and M'hamed CHARROUF \\ Laboratoire de Chimie Organique Biomoléculaire Associé au C.N.R, Faculté des Sciences Ben M'Sik, \\ BP 7955, Casablanca, Maroc
}

R. PAILLER and R. NASLAIN

Laboratoire des Composites Thermostructuraux, Université de Bordeaux I, France

\section{Summary}

Extract of Moroccan oil shale allows us to conclude that these extracts possesses antibacterial activity against Agrobacterium tumefaciens, Escherichia coli, Pseudomonas aerogunosa, Staphylococcus aureus and Enterococcus faecalis, cytotoxicity against larva of Artemia salina and produce metabolites that bind DNA in procedure using HPLC system for detection of antitumor agents.

Keywords : Oil shale, Morocco, Antibacterial, Cytotoxicity, DNA.

\section{Introduction}

Oil shale have constituted for a long time, an economical hope for countries which possesses important reserves of these rocks and view to use them as an energy source substitute for petroleum. Morocco with estimated reserves of 93 billion tons ${ }^{1}$, is increasingly looking at oil shale as an alternative energy source. Previous studies, have concentrated on oil shales located in the Timahdit and Tarfaya because of their high percentage on organic matter ${ }^{2}$. Most of the studies focus either on the effect of various parameters on the yield and the quality of the oil obtained by conventional pyrolysis or on the characterization of these oils by different physical and chemical techniques ${ }^{3}$. This paper is the first report to evaluate biological activities of extracts from the Moroccan oil shale. 


\section{Experimental}

\subsection{Oil shale}

The oil shale specimen used in this investigation was obtained from the Tarfaya formation (Morocco) by the National Office of Petroleum Research and Exploitation.

\subsection{Extraction procedure}

$500 \mathrm{~g}$ sample was exhaustively soxhlet extracted using $\mathrm{CHCl}_{3} / \mathrm{EtOH}(\mathrm{V} / \mathrm{V})$, until the refluxing solvent became clear, we obtained $40.52 \mathrm{~g}$ of black residual solution. These were concentrated by evaporation under reduced pressure. The residual extract was then extracted successively with Hexane, Ether, Dichloromethane, Ethylacetate and Methanol.

\subsection{Bioassays}

Each extract was tested for antibacterial activity, cytotoxicity against larva of Artemia salina, and interaction with DNA.

\subsection{Antibacterial test}

Extracts were tested against five terrestrial bacteria : Escherichia coli, Pseudomonas aeruginosa, Staphylococcus aureus, Enterococcus faecalis and Agrobacterium tumefaciens. Antibacterial assays were conducted using the standard disc-diffusion assay ${ }^{4}$. Extracts were applied to $6 \mathrm{~mm}$ sterile discs in aliquots of $10 \mu \mathrm{l}$ of solvent, allowed to dry at room temperature, and placed on agar plates and incubated at $37^{\circ} \mathrm{C}$ for $24 \mathrm{~h}$. Zones of growth inhibition, if any, were measured following incubation. Product was assayed twice at a concentration of $10 \mu \mathrm{g} \mathrm{disc}^{-1}$.

\subsection{Cytotoxicity test}

Samples were prepared by dissolving extracts in DMSO. Brine shrimp eggs were hatched in a shallow rectangular dish filled with artificial sea water which was prepared with a commercial salt mixture and double-distilled water. After 24 hours the phototropic nauplii were collected by pipette from the lighted side, having been separated by the divider from their shells. Ten shrimps were transfered to each sample vial. The nauplii can be counted macroscopically in the stem of the pipette against a lihgted back-ground.

The vials were maintained under illumination. Survivors were counted, after 24 hours, and the percent deaths at each dose and control (Solvent) were determined ${ }^{5}$. LD50's was determined from the 24 hour counts. The LD50 was derived from the best fit line obtained by linear regression 
analysis, after transforming dose-response data into a straight line by means of a logarithmic transformation.

\subsection{DNA test}

Calf thymus DNA was purchased from Sigma Chemical Co. The HPLC instrument used was a Merck model with spherisob ODS $5 \mu \mathrm{m} 250 \times 4,6 \mathrm{~mm}$ (SFCC) column. The Adriamycine using in reference was purchased from Sigma Chemical Co. DNA solutions were prepared in $\mathrm{H}_{2} \mathrm{O}(0,1$ $\mathrm{mg} / \mathrm{ml})$, and test substances were dissolved in $\mathrm{MeOH}(1,0 \mathrm{mg} / \mathrm{ml})$. The HPLC ODS column was equilibrated with a $\mathrm{H}_{2} \mathrm{O}-\mathrm{MeOH}(80: 20)$ solution. Test samples and DNA solutions were then applied to the HPLC column by pre-mixing the DNA solution with the test sample solution (1:1, $\mathrm{V} / \mathrm{V})$, incubating the mixture at ambient temperature for $30 \mathrm{~min}$, and injecting the mixture $(40 \mu \mathrm{l})$. Inhibition \% was evaluated by comparing the DNA peak sizes (DNA + sample versus DNA alone). Before the following experiment, the column was rinsed $30 \mathrm{~min}$ by $\mathrm{MeOH}$. In order to be sure of good performance of this procedure ${ }^{6}$, we use in reference the Adriamycin, an antitumor agent.

Interaction activity with DNA is exprimed by percentage of loss interaction with regard to control (DNA alone). Inhibition ratio $(\%)=[(\mathrm{A}-\mathrm{B}) / \mathrm{A}] \times 100$, where $\mathrm{A}$ is the area of DNA and $\mathrm{B}$ is that DNA with the extract.

\section{Results and discussion}

\subsection{Antibacterial test}

Antibacterial activity of oil shale extracts was measured as radius of zone of inhibition around the disc (table 1).

In the same way, we have evaluated tetracycline (prepared tetracycline disc) activity against these bacteria. Inhibition zones are, $21,13,20,17$ and $15 \mathrm{~mm}$, respectively against $A$. tumefaciens, $E$. coli, $P$. aerogunosa, S. aureus and E. faecalis

Except Ether extract, all extracts of oil shale are active against bacteria. Agrobacterium tumefaciens is the most sensitive to extracts than others bacteria. Activity of Ethylacetat extract against Escherichia coli is comparable to tetracycline activity. Antibacterial activity has been previously reported from extracts of some natural products and caused growth inhibition in Cram positive and Cram negative bacteria, indicating that these extracts do not selectively inhibit one group of microorganisms ${ }^{7}$. 


\section{Table 1}

Antibacterial activity of oil shale extracts

\begin{tabular}{|c|c|c|}
\hline Bacteria & Extract $(10 \mu \mathrm{g})$ & zone of inhibition $(\mathrm{mm})^{*}$ \\
\hline \multirow{5}{*}{ A. tumefaciens } & Hexane & 13 \\
\hline & Ether & 0 \\
\hline & Dichloromethane & 11 \\
\hline & Ethylacetat & 10 \\
\hline & Methanol & 12 \\
\hline \multirow{5}{*}{ E. coli } & Hexane & 0 \\
\hline & Ether & 0 \\
\hline & Dichloromethane & 0 \\
\hline & Ethylacetat & 12 \\
\hline & Methanol & 10 \\
\hline \multirow{5}{*}{ S. aureus } & Hexane & 10 \\
\hline & Ether & 0 \\
\hline & Dichloromethane & 8 \\
\hline & Ethylacetat & 10 \\
\hline & Methanol & 12 \\
\hline \multirow{5}{*}{ P. aerogunosa } & Hexane & 9 \\
\hline & Ether & 0 \\
\hline & Dichloromethane & 0 \\
\hline & Ethylacetat & 8 \\
\hline & Methanol & 12 \\
\hline \multirow{5}{*}{ E. faecalis } & Hexane & 0 \\
\hline & Ether & 0 \\
\hline & Dichloromethane & 10 \\
\hline & Ethylacetat & 0 \\
\hline & Methanol & 13 \\
\hline
\end{tabular}

* zone of inhibition of solvent $=0 \mathrm{~mm}$

\subsection{Cytotoxicity test}

Oil shale extracts have been tested at $20,40,60$ and $100 \mu \mathrm{g} / \mathrm{ml}$. LD50 values are given in table 2 . 
Table 2

LD50 values of oil shale extracts

\begin{tabular}{|c|c|}
\hline Extract or reference & $L D_{50}(\mu \mathrm{g} / \mathrm{ml})$ \\
\hline Hexane & 32.07 \\
\hline Ether & 41.75 \\
\hline Ethylacetat & 80.67 \\
\hline Dichloromethane & 117.33 \\
\hline Methanol & 192.21 \\
\hline Potassium dichromate & 35.70 \\
\hline Podophyllotoxin & 2.30 \\
\hline
\end{tabular}

In the same way, we have tested potassium dichromate and podophyllotoxin.

Oil shale extracts are toxic against Artemia salina larva, hexane extract was the most cytotoxic, being comparable to potassium dichromate but significantly less active than podophyllotoxin.

A comparaison of toxicity of oil shale extracts with toxicity of some products provided in litterature ${ }^{8}$ shows that all extracts (except Methanol extract) are more toxic than digitaline (LD50 $=$ $151 \mu \mathrm{g} / \mathrm{ml})$ and cafeine $\left(\mathrm{LD}_{50}=306 \mu \mathrm{g} / \mathrm{ml}\right)$.

\subsection{DNA test}

Hexane and Ethylacetat extracts show negative responses, Ether, Dichloromethane and Methanol extracts elicit a positive response. Their Percentages of binding DNA are respectively $17.61,51.62$ and $10.07 \%$.

In the same way, we have evaluated interaction of Adriamycin with DNA, it found to reduce $76 \%$ the DNA peak (fig. 1).

Dichloromethane extract produce a interesting interaction with DNA but less than Adriamycin. This result suggest that oil shale is able to produce compounds that bind DNA.

The results of this test were found in excellent agreement with P388 and KB in vitro cytotoxic activity, and have allowed, for example, to isolation of budmunchiamines from Albizia amarce 9

Recently, it has been described that compounds that interact with nucleic acids are among the most useful cancer chemotherapeutic agents ${ }^{10}$.

In the conclusion, we can say that moroccan oil shale extracts have a interesting bioactives properties. It is envisaged that this paper will lead to a working proposal for the use of moroccan oil shale as source of compounds with pharmaceutical interest. 


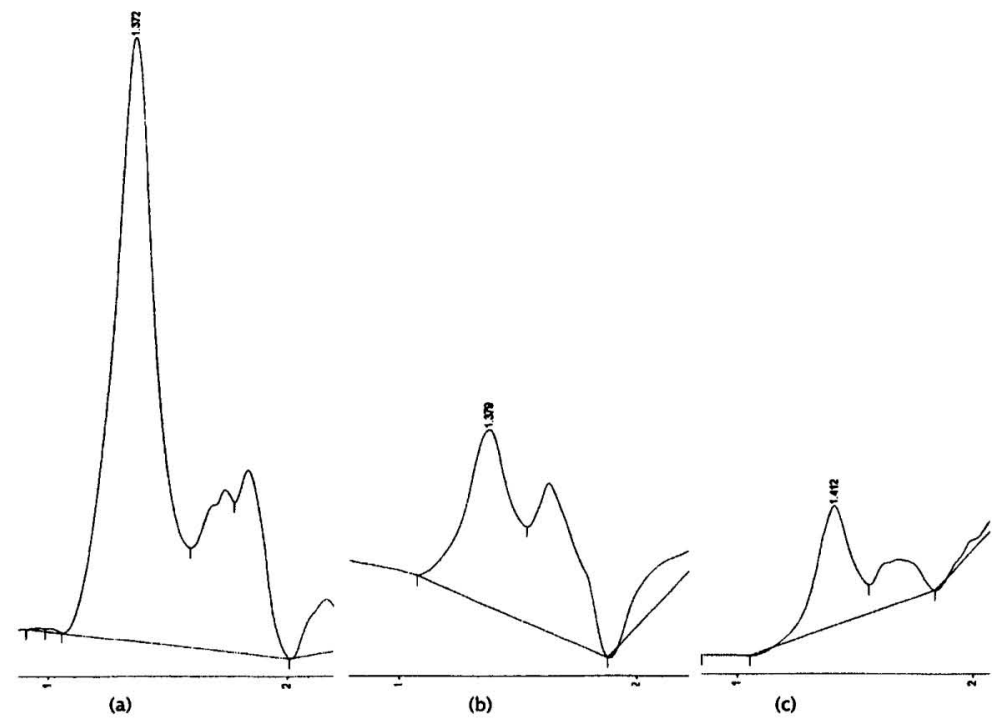

Fig. 1. DNA Affinity of oil shale extracts, detection U.V. $254 \mathrm{~nm}$. ODS HPLC column, $\mathrm{H}_{2} \mathrm{O}-\mathrm{MeOH}(80 / 20)$ eluent.

(a) DNA alone, (b) DNA+Ether extract : a $17.61 \%$ inhibition,

(c) DNA+Dichloromethne extract : a $51.62 \%$ inhibition

\section{References}

[1] Alpern B. (1981), Bull. Centre Rech. Explor. Prod. Elf Aquatique. $52: 319$.

[2] Tahiri M., Sliepcevich, C.M., Mallinson R.G. (1987), ACS, division of petroleum chemistry. $32: 71$.

[3] Elharfi K., Mokhlisse A.,BenChanâa M. (1999), Journal of pyrolysis. $48: 65$.

[4] McCaffrey E.J., Erdean R. (1985), Mar. Biol. 89 : 1.

[5] Meyer B.N., Ferrigni N.R., Putnam J.E., Jacobsen L.B., Nichols D.E., McLaughlin J.L. (1982), Planta Med. $45: 31$

[6] Pezzuto J.M., Taoche C., McPherson D.,Pingzhu J.L., Topcu G., Erdelmeier C.A.J., Cordell G.A. (1991), J. Nat. Prod 54 : 1522.

[7] Schmitz F.J., Yasumoto T. (1991), J. Nat. Prod. 54 : 1469.

[8] Mar W., Tang T., Cordell G.A., Pezzuto J.M., Jurcic K., Offermann F., Redl K., Steinke B., Wagner H. (1991), J. Nat. Prod. 54 : 1531.

[9] Burres N., Frigo A., Rasmussen R., McAlpine J. (1992), J. Nat. Prod. 55: 1582.

[10] Stingl J., Andersen R.J., Emerman J.T. (1992), Cancer chemother pharmacol, 30 : 401. 